\title{
日本での研究生活
}

\section{ムハマド ロムジ*}

わたしは 1990 年 4 月 4 日にインドネシア政府 派遣留学生として来日した。そして、国際学友会日 本語学校で 1 年間の日本語教育を受講して、福井 大学情報工学科に入学した。ここでわたしは正規 の日本の大学教育を 4 年間に受けた。しかし、その 時の学生生活を考えてみれば、授業中の学生達の 積極性がみられなく、また学生はグループごとに 分れて、同じ学科でも他人の名前の知らない学生 が多くみられる。今でもそうであろうと思う。話に よると、大学に入ってからではなく、高校の時、ひ どければ中学校の時から、もう仲間割れの状態で 学校生活をすごしてきた学生が少なくないそうだ。 これは最近、問題になっている「いじめ」が起こり やすい環境の 1 つだとわたしは思う。同心゙学科、同 じクラスの友達に何かが起こったという時に、周 りの友達のなかで誰も知らないという現象は、わ たしにはとても考えられないことである。

話しは脱線したが、情報工学科には、知識情報処 理研究室があり、知識表現、知識獲得、知識処理の 分野を中心にさまざまなソフトウェアの研究をお こなっている。ここで、わたしは小倉久和教授と小 高知宏助教授の指導を受け、ファジィ制御を用い て、制御知識の表現・処理の研究を行なった。

当研究室では様々な研究活動が行なわれている。 週に 2 回のゼミと 1 回の進捗会という研究関連の 進捗状沉、問題点及び問題解決を話し合う機会が あり、また、年に 3 回の中間報告会もある。そして 最後には、学会で発表する研究活動などがある。わ たしも当研究室に入ってからわずか 2 ケ施らい で、小倉先生にファジィの研究会に参加しない?と

* Muchammad Romzi

福井大学工学部情報工学科
声かけられた。確かに、わたしの研究テーマは前年 度の卒業生の研究を引き継いだものだったが、し かし、約 2 3 ケ月間にその研究内容をどう把握す るか、どう改善するか、また、どうまとめるかとい う心配があった。しかしわたしは何故かその誘い を断われぬまま、むしろ前向きな考え方を取ろう とした。その理由はおそらく、小含先生と小高先生 の指導を受ければかならず何とかなるという信頼 性が高かったからにほかならない。結果的に、わず か数ヶ月間で研究の内容を把握することができ、 前年度のプログラムのバグを発見し、そして改善 した。さらに新しい機能の試みを行ない、これらの 研究成果をその年の 8 月に行なわれた日本ファジ イ学会北信越支部主催のファジィミニシンポジウ ムで発表した。

以前、国際学友会日本語学校で日本語を勉強し ていた時に、日本語でのスピーチコンテストに参 加したことはあったが、学会では全く違う雾囲気 である。わたしは学会とは様々な専門分野の知識 を持つ学生や研究者の前で自分の考え方をどう伝 えるか、また素朴な質問から専門的な質問まで、そ れらに対してどう答えるか等について勉強する場 所だと思っている。それだけではなく、仲間を作る 場所でもある。この素晴しい機会を与えて下さっ た先生達に感謝の意を表したいと思う。

そして、卒業論文「倒立振子系の姿勢制御知識の 獲得と適応制御システム」をまとめて、1995 年の 3 月に卒業した。例年、卒業諭文をまとめる時期 は、当研究室は他所の研究室より比べると忙しい。 というのは、学科の論文締切よりかなり早い時期 に当研究室の第一締切、第二締切、そしてデッドラ インがあり、先生達に添削をしてもらわなければ 
ならない。特にわたしの場合は論文の内容的なこ ともあるが、日本語の添削もあるので、大変幸い時 期だった。しかし、よく考えてみれば先生達の方は 十数人の論文を一度に添削するので、それ以上に この時期はとても大変な時期だと思う。これは学 会の隼備のときもそうである。原稿が完成だ!と思 うまで先生方に何度も添削してもらい、発表練習 も何度も行った。まず、一度で通して下さることは ない。論文の内容だが、具体的には、制御対象とし ての倒立二重振子の挙動をエキスパート制御知識 のプロダクション (if-then) 形式であるファジィル ールで表現し、ファジィ推論を用いてロバストな 制御を試みるものである。詳しいことは日本ファ ジィ学会誌、Vol.8、No.3、pp.576-585（1996）に掲 載されている「倒立二重振子に対するファジィ制 御知識の表現とスケーリングによる適応制御」と いうわたしの論文を参照して下さい。

同年 4 月に同大学の大学院工学研究科博士前期 課程情報工学専攻に入学した。入学後、奨学金はイ ンドネシア政府ではなく、日本の文部省から支給 されることになった。奖学金支給期間は 2 年であ る。研究業績に対してこんなに高い評価をもらつ たのは小倉研究室の先生方のおかげであることは 間違いがない。入学後でも引き続き小倉久和教授 と小高知宏助教授の指導を受け、研究を行なった。 その研究を完成させて論文としてまとめ、日本フ アジィ学会に投稿し、昨年の秋に受理された。上に 紹介した論文がそれである。この論文の受理後、新 たにPowerPC 601-IBM RS/6000というパーソ ナルワークステーションを購入してもらい、研究 を続けている。現在、これまで行なった研究をさら に発展させ、遺伝的アルゴリズムを用いた手法に より、制御知識の表現と最適化の工夫を行ない、論 文としてまとめているところである。この研究テ ーマについても学会、地方研究会、全国大会、さら にシンポジウムにおいて発表してきた。また、これ までの研究分野をさらに広げるため、オペレーシ ョンズリサーチや経営工学における意思決定プロ セスで重要な多目的最適化の研究を現在行なって いる。具体的には、GA を用いて多目的ナップザッ
ク問題におけるパレート最適解の集合を求める研 究である。この研究はまだ数ヶ月前に始めたばか りではあるが、既に学会で報告した。このように、 いままでいろいろな学会に出席したおかげで、自 分の研究テーマに対する考え方が広がったと思っ ている。

マスターになってからは、研究活動がさらに数 倍になった。年に最低 1 回ぐらいの学会発表はも ちろんのこと、当研究室のシステム管理者や卒研 生を対象にして、各自のシステム環境の設定のた めの勉強会、来年度からマス夕一になる卒研生に 対しての IL(Initial Lecture) と呼ぶシステム管理 者講習会などがあり、忙しい每日である。もちろん マスターの授業もあるが、こんな生き生きしてい る研究活動を当研究室で経験でき、ありがたく思 っている。

昨年、1995 年の 10 月に当研究室に東京工業大 学出身の西野順二助手が来られた。西野先生も知 識豊富な方で、よく当研究室の学生達の面倒をみ て下さる。わたし自身は改めてこの研究室に入っ てよかったなと思っている。こんな素晴しい先生 方と設備に恵まれているからこそわたしはここま で歩んでこられたと思う。

来年の 3 月に今年度で前期課程は修了するが、 来年度後期課程 $(\mathrm{DC})$ への進学を考えて、試験を受 け合格した。もし奖学金支給期間の延長が許可さ れたら、今後 3 年間、この研究室で研究を続けたい と思う。しかし、できない場合は帰国し、インドネ シア政府機関の中央統計局 (Central Bureau of Statistics)に勤務する予定である。この場合でも、 帰国後も、小倉久和教授、小高知宏助教授及び西野 順二助手と連絡をとり、情報交換や語查研究を継 続して行こうと考えてる。

[問い合わせ先]

Muchammad Romzi

J1. Gresik Gadukan 336

Surabaya 60178, Jawa Timur

INDONESIA

TEL : +62-31-74-90737 
干 910 福井市文京 3-9-1

福井大学工学部情報工学科

ムハマド ロムジ

TEL : 0776-27-8926

FAX : 0776-27-8751 (学科)

E-mail : muhamado@ rook.fuis.fukui-u.ac.jp

[滞在期間 $] 7$ Years

著者紹介

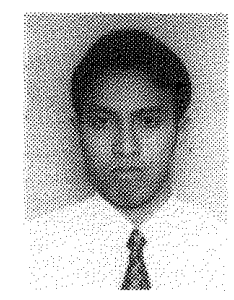

Muchammad Romzi (ムハマドロムシ)

福井大学大学院工学研究科

平成 7 年 福井大学工学部情報工学科

卒業。現在同大学院工学研究科博士前期

課程情報工学専攻在学中。ファジィ制御,

知識獲得、遺伝的アルゴリズムの研究に

従事。情報処理学会の会員。 